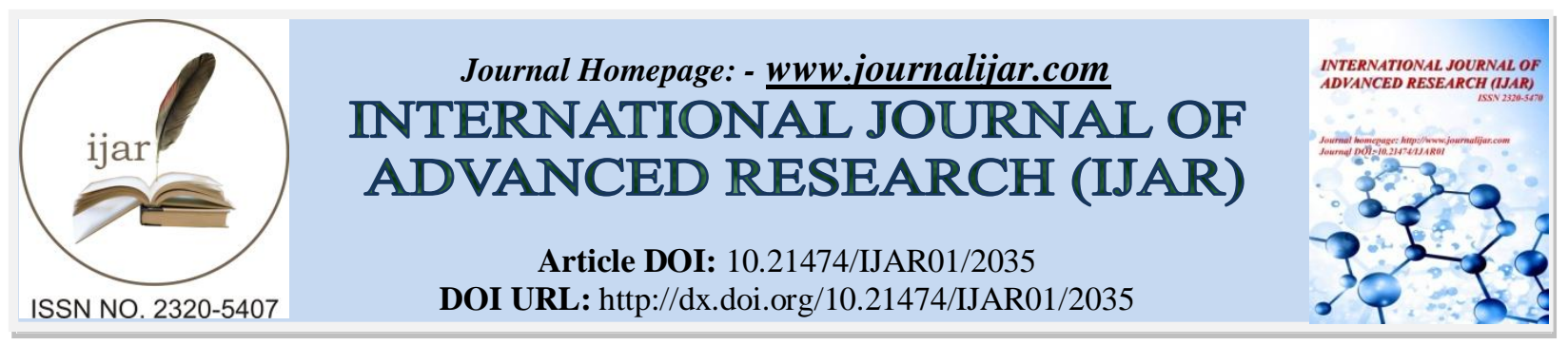

RESEARCH ARTICLE

\title{
EFFECT OF DIFFERENT TRANSPLATING DATES ON GROWTH AND YIELD OF DIFFERENT CAULIFLOWER VARIETIES.
}

M.Hanuman Naik ${ }^{1}$, M.Ravindra Babu ${ }^{2}$ and D.Lakshminarayana ${ }^{3}$.

1. Scientist (Hort) \& Head, Horticultural Research Station, Aswaraopet, SKLTHU.

2. Scientist (Hort), Horticultural Research Station, V.R.Gudem, Dr.YSRHU.

3. Assistant Professor (Hort), College of Horticulture, Mojerla, SKLTHU.

\section{Manuscript Info}

\section{Manuscript History}

Received: 27 September2016

Final Accepted: 12 October 2016

Published: October 2016

Key words:-

Cauliflower, transplanting dates, varieties, curd yield

\section{Abstract}

A field experiment was conducted with an objective to study the performance of different cauliflower varieties at different dates of transplanting at Horticultural Research Station, Aswaraopet, Khammam Dist of Telangana State. All the parameters were influenced by cultivars and transplanting dates. Maximum yields were obtained in all the cultivars by transplanting in the month of October. Highest curd weight and highest marketable yield were recorded in NS $60 \mathrm{~N}$ which is on par with SC 60 and Basant. Among interactions NS $60 \mathrm{~N}$ transplanted during October recorded highest marketable yield (12.07 t/ha) which was on par with SC 60 transplanted during October (12.04 t/ha) and Basant transplanted during October (11.01 t/ha).

Copy Right, IJAR, 2016,. All rights reserved.

\section{Introduction:-}

Cauliflower (Brassica oleracea var. botrytis L.) belongs to the family Brassicaceae whose curd i.e. white edible modified inflorescence is used as vegetable. It is one of the most important cole crops grown under temperate to tropical climatic conditions. It is a rich source of minerals like $\mathrm{P}, \mathrm{K}, \mathrm{Ca}, \mathrm{Na}$ and $\mathrm{Fe}$. It is grown all over India in varied climatic conditions in an area of 4.34 lakh hectares with a production of 85.73 lakh tonnes and productivity of 19.8 t/ha (NHB, 2014). Cauliflower is a heat sensitive crop and temperature plays most important role in curd formation and quality of the curd. The varieties fail to give best performance if there is slight deviation in the transplanting time. High temperatures during curd development and maturity period increases defective curds and deteriorate the quality of curds. Singh (2007) reported that the optimum temperature for curd formation is $15.2{ }^{0} \mathrm{C}$ with an average maximum of $25{ }^{\circ} \mathrm{C}$ and minimum of $8{ }^{\circ} \mathrm{C}$. According to Gill and Sharma (1996) transplanting times depend on the varieties and the agroclimatic conditions prevailing in a particular region. Early varieties of cauliflower usually grown during summer months in hilly areas can be grown during winter season at warmer climate. Hence, present investigation was taken up to evaluate different cauliflower varieties at different dates of transplanting.

\section{Material and Methods:-}

The experiment was carried out at Horticultural Research Station, Aswaraopet, Khammam district of Telangana state situated at $17^{\circ} 15^{`} 00.5^{\prime \prime} \mathrm{N}, 80^{\circ} 06^{\prime} 00.6^{\prime} \mathrm{E}$ and $166 \mathrm{~m}$ above mean sea level during 2009-10 and 2011-12. The soil is red sandy loam with $\mathrm{P}^{\mathrm{H}}$ of 6.7. The experiment was laid out in factorial RBD with two factors i.e, dates of transplanting and varieties with three replications. The treatments comprised of three different dates of transplanting 
viz. September, October and November, and four hybrids viz. Basant, NS 60 N, SC 60 and Swetha early. The field was prepared by applying uniform dose of FYM @ 20 t/ha was applied to the plots uniformly at final ploughing. The NPK fertilizers @ 150:200:100 Kg/ha were applied through Urea, SSP and MOP respectively. Thirty days old seedlings at 4-5 leaf stage were transplanted at spacing of $60 \mathrm{X} 45 \mathrm{~cm}$ in the plots of $3.0 \mathrm{X} 2.7 \mathrm{~m}$ size to accommodate thirty plants in each plot. All the standard package of practices and plant protection measures were adopted time to time to grow the crop successfully. The Horticultural parameters were recorded with respect to plant height $(\mathrm{cm})$, number of leaves per plant, number of days for curd initiation, number of days for curd development, curd diameter $(\mathrm{cm})$, curd weight $(\mathrm{gm})$ and marketable yield (t/ha) from ten randomly selected plants in each treatment and replication. Data collected were subjected to statistical analysis suggested by Pasne and Sukhatane (1985).

\section{Results and Discussion:-}

Plant height was highest when cauliflower was transplanted during October $(34.05 \mathrm{~cm})$ and least in September transplanting $(29.76 \mathrm{~cm})$. Among all the four varieties plant height was highest in Sweta early $(33.65 \mathrm{~cm})$ which was on par with NS $60 \mathrm{~N}(31.84 \mathrm{~cm})$ and SC $60(31.78 \mathrm{~cm})$. Among interactions Sweta early transplanted during October recorded highest plant height $(35.52 \mathrm{~cm})$ which was on par with Sweta early transplanted during November $(34.45 \mathrm{~cm}), \mathrm{SC} 60$ transplanted during October $(34.28 \mathrm{~cm})$, NS $60 \mathrm{~N}$ transplanted during October $(34.21 \mathrm{~cm})$ and Basant transplanted during October $(32.18 \mathrm{~cm})$. Lowest plant height was recorded in Basant transplanted during September $(28.22 \mathrm{~cm})$.

Number of leaves per plant was highest in September transplanting $(31.93 \mathrm{~cm})$ which was on par with October transplanting (31.91) and least number of leaves per plant was recorded in November transplanting (28.76). Among the four varieties Sweta early recorded highest number of leaves (32.49) and least number of leaves was recorded in Basant (29.77) which is on par with SC 60 (30.63) and NS 60 N (30.57). Among interactions Sweta early transplanted during October recorded highest number of leaves per plant (33.48) which was on par with all other treatments expect Basant transplanted during November (27.82), NS $60 \mathrm{~N}$ transplanted during November (28.08) and SC 60 transplanted during November (28.08). Least number of leaves was recorded in Basant transplanted during November (27.82).

Number of days for curd initiation was least in November transplanting (79.40) and highest in September transplanting (95.69). Among four varieties tested SC 60 recorded least number of days for curd initiation (84.37) which was on par with NS $60 \mathrm{~N}$ (84.51) and Basant (85.43). Among interactions SC 60 transplanted during November recorded least number of days for curd initiation (75.27) which was on par with NS $60 \mathrm{~N}$ transplanted during November (75.62) and Basant transplanted during November (75.80). Highest number of days for curd initiation was recorded in Sweta early transplanted during September (101.23).

Number of days for curd development was lowest in November transplanting (11.31) and highest in September transplanting (12.55) which was on par with October transplanting (12.39). Among four different varieties Basant recorded least number of days for curd development (11.43) which was on par with NS $60 \mathrm{~N}$ (11.54) and SC 60 (11.71), whereas highest number of days for curd development was noticed in Sweta early (14.13). Among interactions Basant transplanted during November recorded least number of days for curd development (10.89) which was on par with NS $60 \mathrm{~N}$ and SC 60 transplanted during November (11.02), Basant transplanted in the month of September (11.52), NS $60 \mathrm{~N}$ transplanted in the month of September (12.00), Basant transplanted in the month of October (11.60) and SC60 transplanted during October (11.85). Number of days for curd development was highest in Sweta early transplanted during September (14.42) which was on par with Sweta early transplanted during October (14.25) and Swetha early transplanted during November (13.72).

Among different dates of transplanting October transplanting recorded maximum curd diameter $(12.26 \mathrm{~cm})$, whereas minimum curd diameter $(12.26 \mathrm{~cm})$ and least curd diameter was recorded in September transplanting $(11.16 \mathrm{~cm})$ which was on par with November transplanting $(11.31 \mathrm{~cm})$. Among different varieties NS $60 \mathrm{~N}$ and SC 60 recorded highest curd diameter was recorded in Sweta early $(9.93 \mathrm{~cm})$. Among interaction treatments SC 60 transplanted during October recorded highest curd diameter $(13.14 \mathrm{~cm})$ which was on par with NS $60 \mathrm{~N}(12.96 \mathrm{~cm})$ and Basant $(12.43 \mathrm{~cm})$ transplanted during October. Least curd diameter was recorded in Sweta early transplanted during September $(9.23 \mathrm{~cm})$ which was on par with Sweta early transplanted during November $(10.07 \mathrm{~cm})$. Maximum curd diameter might be due to availability of congenial climatic conditions which resulted in proper crop growth and curd development. 
Table :- Performance of different cauliflower varieties at different dates of Transplanting (Pooled data of 2009-10, 2010-11 and 2011-12)

\begin{tabular}{|c|c|c|c|c|c|c|c|}
\hline Treatment & $\begin{array}{l}\text { Plant ht } \\
\text { (cm) }\end{array}$ & $\begin{array}{c}\text { No of } \\
\text { leaves per } \\
\text { plant }\end{array}$ & $\begin{array}{l}\text { No of days for } \\
\text { curd initiation }\end{array}$ & $\begin{array}{c}\text { No of days for } \\
\text { curd } \\
\text { development }\end{array}$ & $\begin{array}{c}\text { Cur } \\
\text { diameter } \\
(\mathbf{c m})\end{array}$ & $\begin{array}{c}\text { Curd } \\
\text { weight } \\
\text { (gm) }\end{array}$ & $\begin{array}{l}\text { Marketable } \\
\text { Yield (t/ha) }\end{array}$ \\
\hline \multicolumn{8}{|c|}{ Dates of transplanting } \\
\hline September & 29.76 & 31.93 & 95.69 & 12.55 & 11.16 & 231.06 & 7.27 \\
\hline October & 34.05 & 31.91 & 87.25 & 12.39 & 12.26 & 342.68 & 10.78 \\
\hline November & 31.89 & 28.76 & 77.40 & 11.66 & 11.31 & 266.56 & 8.36 \\
\hline \multicolumn{8}{|c|}{ Varieties } \\
\hline Basant & 30.32 & 29.77 & 85.43 & 11.43 & 11.85 & 286.64 & 9.01 \\
\hline NS $60 \mathrm{~N}$ & 31.84 & 30.57 & 84.51 & 11.54 & 12.26 & 312.19 & 9.81 \\
\hline SC 60 & 31.78 & 30.63 & 84.37 & 11.71 & 12.26 & 307.87 & 9.66 \\
\hline Sweta Early & 33.65 & 32.49 & 92.76 & 14.13 & 9.93 & 213.70 & \\
\hline \multicolumn{8}{|c|}{ Interactions } \\
\hline SV1 & 28.22 & 30.34 & 95.00 & 11.52 & 11.63 & 242.36 & 7.61 \\
\hline SV2 & 30.27 & 32.00 & 93.35 & 12.00 & 11.95 & 263.97 & 8.28 \\
\hline SV3 & 29.57 & 32.43 & 93.15 & 12.25 & 11.82 & 247.67 & 7.78 \\
\hline SV4 & 30.98 & 32.93 & 101.23 & 14.42 & 9.23 & 170.23 & 5.34 \\
\hline OV1 & 32.18 & 31.16 & 85.60 & 11.87 & 12.43 & 350.20 & 11.01 \\
\hline OV2 & 34.21 & 31.62 & 84.57 & 11.60 & 12.96 & 384.13 & 12.07 \\
\hline OV3 & 34.28 & 31.39 & 84.70 & 11.85 & 13.14 & 383.73 & 12.04 \\
\hline OV4 & 35.52 & 33.48 & 94.15 & 14.25 & 10.51 & 252.65 & 7.94 \\
\hline NV1 & 30.57 & 27.82 & 75.80 & 10.89 & 11.49 & 267.36 & 8.40 \\
\hline NV2 & 31.05 & 28.08 & 75.62 & 11.02 & 11.88 & 288.47 & 9.07 \\
\hline NV3 & 31.48 & 28.08 & 75.27 & 11.02 & 11.82 & 292.22 & 9.18 \\
\hline NV4 & 34.45 & 31.06 & 82.90 & 13.72 & 10.07 & 218.21 & 6.85 \\
\hline \multicolumn{8}{|l|}{ C.D (0.05) } \\
\hline Factor A & 2.15 & 1.50 & 2.09 & 0.28 & 0.51 & 29.68 & 1.18 \\
\hline Factor B & 1.81 & 1.73 & 2.42 & 0.32 & 0.59 & 34.27 & 1.28 \\
\hline $\mathrm{A} \times \mathrm{B}$ & 3.73 & 4.28 & 4.56 & 1.16 & 1.09 & 53.50 & 2.35 \\
\hline Treatment & $\begin{array}{l}\text { Plant ht } \\
\text { (cm) }\end{array}$ & $\begin{array}{c}\text { No of } \\
\text { leaves per } \\
\text { plant }\end{array}$ & $\begin{array}{l}\text { No of days for } \\
\text { curd initiation }\end{array}$ & $\begin{array}{c}\text { No of days for } \\
\text { curd } \\
\text { development }\end{array}$ & $\begin{array}{c}\text { Cur } \\
\text { diameter } \\
(\mathbf{c m})\end{array}$ & $\begin{array}{c}\text { Curd } \\
\text { weight } \\
\text { (gm) }\end{array}$ & $\begin{array}{l}\text { Marketable } \\
\text { Yield (t/ha) }\end{array}$ \\
\hline \multicolumn{8}{|c|}{ Dates of transplanting } \\
\hline September & 29.76 & 31.93 & 95.69 & 12.55 & 11.16 & 231.06 & 7.27 \\
\hline October & 34.05 & 31.91 & 87.25 & 12.39 & 12.26 & 342.68 & 10.78 \\
\hline November & 31.89 & 28.76 & 77.40 & 11.66 & 11.31 & 266.56 & 8.36 \\
\hline \multicolumn{8}{|c|}{ Varieties } \\
\hline Basant & 30.32 & 29.77 & 85.43 & 11.43 & 11.85 & 286.64 & 9.01 \\
\hline NS $60 \mathrm{~N}$ & 31.84 & 30.57 & 84.51 & 11.54 & 12.26 & 312.19 & 9.81 \\
\hline SC 60 & 31.78 & 30.63 & 84.37 & 11.71 & 12.26 & 307.87 & 9.66 \\
\hline Sweta Early & 33.65 & 32.49 & 92.76 & 14.13 & 9.93 & 213.70 & \\
\hline \multicolumn{8}{|c|}{ Interactions } \\
\hline SV1 & 28.22 & 30.34 & 95.00 & 11.52 & 11.63 & 242.36 & 7.61 \\
\hline SV2 & 30.27 & 32.00 & 93.35 & 12.00 & 11.95 & 263.97 & 8.28 \\
\hline SV3 & 29.57 & 32.43 & 93.15 & 12.25 & 11.82 & 247.67 & 7.78 \\
\hline SV4 & 30.98 & 32.93 & 101.23 & 14.42 & 9.23 & 170.23 & 5.34 \\
\hline OV1 & 32.18 & 31.16 & 85.60 & 11.87 & 12.43 & 350.20 & 11.01 \\
\hline OV2 & 34.21 & 31.62 & 84.57 & 11.60 & 12.96 & 384.13 & 12.07 \\
\hline OV3 & 34.28 & 31.39 & 84.70 & 11.85 & 13.14 & 383.73 & 12.04 \\
\hline OV4 & 35.52 & 33.48 & 94.15 & 14.25 & 10.51 & 252.65 & 7.94 \\
\hline NV1 & 30.57 & 27.82 & 75.80 & 10.89 & 11.49 & 267.36 & 8.40 \\
\hline NV2 & 31.05 & 28.08 & 75.62 & 11.02 & 11.88 & 288.47 & 9.07 \\
\hline NV3 & 31.48 & 28.08 & 75.27 & 11.02 & 11.82 & 292.22 & 9.18 \\
\hline NV4 & 34.45 & 31.06 & 82.90 & 13.72 & 10.07 & 218.21 & 6.85 \\
\hline \multicolumn{8}{|l|}{ C.D (0.05) } \\
\hline Factor A & 2.15 & 1.50 & 2.09 & 0.28 & 0.51 & 29.68 & 1.18 \\
\hline Factor B & 1.81 & 1.73 & 2.42 & 0.32 & 0.59 & 34.27 & 1.28 \\
\hline $\mathrm{A} \times \mathrm{B}$ & 3.73 & 4.28 & 4.56 & 1.16 & 1.09 & 53.50 & 24.85 \\
\hline
\end{tabular}


Among three dates of transplanting October transplanting recorded highest curd weight (342.68 gm) and the least curd weight was recorded in September transplanting (231.06 gm) which was on par with November transplanting (266.56 gm). Among four varieties tested NS $60 \mathrm{~N}$ recorded highest curd weight (312.19 gm) which was on par with SC 60 (307.87 gm) and Basant (286.64 gm). Among interactions NS $60 \mathrm{~N}$ transplanted in the month of October recorded highest curd weight (384.13 gm) which was on par with SC 60 (383.73 gm) and Basant (350.20 gm) transplanted in the month of October. Lowest curd weight was recorded in Sweta early transplanted during September (170.23 gm) which was on par with Sweta early transplanted during November (218.21 gm). Least curd weight was recorded in September and November transplanting which was in agreement with the observations made by Jana and Mukhopadyay (2006), Ajithkumar and Savani (2007).

Among three dates of transplanting October transplanting recorded highest marketable yield (10.78 t/ha) and the lowest yield was recorded in September transplanting $(7.27 \mathrm{t} / \mathrm{ha}$ ) which was on par with November transplanting (8.36 t/ha). Among the four varieties tested highest marketable yield was recorded in NS $60 \mathrm{~N}$ (9.81 t/ha) which was on par with SC 60 (9.66 t/ha) and Basant (9.01 t/ha) and the lowest marketable yield was recorded in Swetha early (6.72 t/ha). Among interactions NS $60 \mathrm{~N}$ transplanted during October recorded highest marketable yield (12.07 t/ha) which was on par with SC 60 transplanted during October (12.04 t/ha) and Basant transplanted during October (11.01 t/ha). Lowest marketable yield was recorded in Sweta early transplanted during September (5.34 t/ha) which was on par with Sweta early transplanted during November (6.85 t/ha) and Basant transplanted during September (7.61t/ha). Yield and its components are polygene in nature and hence influenced by environmental factors (Meena et al, 2010). The reduction in the yield might be due to unfavourable climatic conditions prevailed during crop growth. The present results are in conformity with Bharadwaj and Sharma (1996)

\section{Conclusion:-}

From the above findings it may be concluded that NS $60 \mathrm{~N}$ and SC 60 are suitable for cultivation by transplanting in the month of October under subtropical climatic conditions of Aswaraopet, Khammam district of Telngana state.

\section{References:-}

1. Ajith kumar. B and Savani. M. B. 2007. Phasic development model for Cauliflower (Brassica oleracea var. botrytis) using thermal indices. J Agromet 9 (2): 231-235.

2. Bharadwaj M.L, and Sharma P.P, 1996. Studies on seed production in Indian cauliflower under sub-tropical regions of Himachal Pradesh. Indian Journal of Horticulture. 53(3):206-209.

3. Gill H S and Sharma S R (1996). Cole crops. In: Paroda, R. S. and Chadha, K. L. (eds.), 50 Years of Crop Science Research in India. Indian Council of Agricultural Research, New Delhi,pp. 635-645.

4. Indian Horticulture Database, 2014, NHB(National Horticulture Board) available at http://nhb.gov.in/areapro/NHB_Database_2015.pdf

5. Jana J. C and Mukhopadhyay T. P, 2006. Effect of sowing dates and varieties on growth and curd yield of Cauliflower in terai zone of West Bengal. Orissa J Hort., 34(1): 45-48.

6. Kanwar. J.S, 1994. Effect of sowing date on seed yield of cauliflower. Seed Research. 22(1):69-70.

7. Meena M.L, Ram R.B, Lata. R, Sharma S.R, 2010. International Journal of Science and Nature, 1: 27-30.

8. Singh D.K, International book distributing co, 2007, Lucknow, 159 p. 